MÁTYÁS BÓDIG*

\title{
Legal Interpretation, Intentionalism, and the Authority of Law**
}

\begin{abstract}
The essay reflects upon the debate over intentionalism about statutory interpretation, and argues for a moderate version of intentionalism. It argues that the debate over intentionalism cannot be sorted out without establishing a viable conception of legislative authority. The outlines of such a conception are put forward by throwing some light on the concept of "representational authority". The essay also argues that the problem of legal interpretation touches upon issues of sovereignty. It implies that some important issues of the normative theory of legal interpretation are linked to substantive political philosophical problems.
\end{abstract}

Keywords: interpretation, normative theories of legal interpretation, intentionalism, representational authority, sovereignty union

\section{Introduction}

The following essay is a contribution to the age-old debate among jurists over the proper role of legislative intentions in statutory interpretation. The debate plays out in legal theory as the controversy between intentionalists and nonintentionalists. Intentionalists claim that legislative intentions play an important role in statutory interpretation. Non-intentionalists, on the other hand, insist that legislative intentions cannot have that role: intentionalist methods are forbidden in the legal practice. ${ }^{1}$ My analysis will present an incomplete argument for a version of intentionalism about statutory interpretation. The argument is based

* Research Fellow, Institute for Legal Studies, H-1014, Budapest, Országház u. 30. Hungary.

E-mail: mbodig@mailbox.hu

** A version of this paper was presented in the research seminar series of the Institute for Advanced Studies in the Humanities at the University of Edinburgh in October 2005. I would like to thank Zenon Bankowski, Mátyás Bencze, Timothy Chapell, Stephen Latham and Geoff Parker for their comments.

${ }^{1}$ See Moore, M.: Interpreting Interpretation. In: Marmor, A. (ed.): Law and Interpretation: Essays in Legal Philosophy. Oxford, 1995. 24. 
on certain conceptual considerations concerning the authority of statutory provisions.

I deliberately employ here a rather broad and weak formulation of intentionalism that does not refer to one particular interpretive method. ${ }^{2}$ Intentionalism, as I depict it here, can take several forms. One option is linking the intentionalist position to the well-known view that textual interpretation is about retrieving authorial intentions, and regarding legislators as the authors of statutes. Another option is the claim that, although textual interpretation is not necessarily about retrieving intentions, there is something special about legal interpretation that vindicates intentionalist interpretive strategies. And an intentionalist can also claim that intentionalist interpretive strategies should play a vital but only partial role in legal interpretation.

As the preliminary remarks should make it obvious, the present essay concentrates on the problems of normative theories of legal interpretation that engage with norms that determine what qualifies as a successful legal interpretation or as a justifiable interpretive strategy. For this reason, I do not undertake to defend here any descriptive theory of legal interpretation. However, each normative theory of legal interpretation presupposes something that belongs to the realm of descriptive theories: a plausible account of the process and the constitutive features of legal interpretation. Without such an account in its background, a normative theory of legal interpretations is totally irrelevant. For this reason, it may be useful to reveal the main conceptual points about interpretation and legal interpretation that I will rely on. As this is not the task of the present analysis, I do not provide arguments for them, but I hope that they are not too controversial, and will not scare off my potential readers.

First, a few words on interpretation itself. When we talk about interpretation, we tend to treat textual interpretation as the central case. As the subject of my paper is statutory interpretation, this is not at all against my intentions. However, for philosophical reasons, it is better to settle for a more general definition. Interpretation is one of the activities directed towards understanding meaning. ${ }^{3}$ Of course, its theoretical problem is not identical with that of understanding meaning: interpretation actually presupposes the ability of understanding

\footnotetext{
2 In light of the wide variety of the uses of the "argument from intention", it would seem rather odd to talk about one particular intentionalist interpretive method. Cf. MacCormick, N.-Summers, R. S.: Interpretation and Justification. In: MacCormick, N.Summers, R. S. (eds.): Interpreting Statutes: A Comparative Study. Aldershot, 1991. 522525.

See Moore: op. cit. 2.
} 
meaning. ${ }^{4}$ Interpretation is required when understanding meaning is problematic in a distinctive way: having access to the pertinent meanings requires some effort that is within the scope of our linguistic skills. ${ }^{5}$ Interpretation should be taken as a process that substitutes one linguistic expression for another. ${ }^{6}$ When we effortlessly understand the meaning, which is very often the case, ${ }^{7}$ interpretation is not necessary. When the meaning to be understood transcends our linguistic skills (e.g. when someone speaks to us in a language that we are not familiar with), interpretation cannot be successful.

As to legal interpretation, the crucial preliminary point is that I take it to be strongly connected to legal reasoning. The theoretical problem of legal interpretation is a part of the broader theoretical problem of legal reasoning. The link between the two problems is established by the fact that, in modern legal systems, legal reasoning normally has to rely on reasons that are drawn from recognized sources. It is also characteristic of modern legal systems that the law authenticated by the recognised sources is incorporated in written legal documents ("legal texts"). Legal reasoning often has to rely on textual interpretation to have access to the relevant legal reasons. Legal reasoning must be capable of providing a proper reading of legal texts. It is also important that when legal theorists or lawyers speak of legal interpretation they tend to think of a specific interpretive activity that figures in the process of making particular legal decisions, and I will be no exception. Although a whole series of interesting theoretical problems arise from other activities that can also be associated with interpreting law (like following or violating the law, or designing new laws), the present analysis will ignore them.

Of course, there are several kinds of legal texts, and they are all proper objects of legal interpretation. One can interpret judicial or administrative decisions or even international treaties. But as I have chosen the controversy

4 See Marmor, A.: Interpretation and Legal Theory. Oxford, 1992. 21. This implies the rejection of the view that the theoretical problem of interpretation, at least sensu largo, covers the whole problem of understanding. For such a view, see Bankowski, Z.MacCormick, N.-Summers, R. S.-Wroblewski, J.: Method and Methodology. In: MacCormick-Summers (eds.): Interpreting Statutes...op. cit. 12.

5 Dummett, M.: A Nice Derangement of Epitaphs: Some Comments on Davidson and Hacking. In: LePore, E. (ed.): Truth and Interpretation: Perspectives on the Philosophy of Donald Davidson. Oxford, 1986. 463.

${ }^{6}$ Of course, making this point has a Wittgensteinian pedigree (although the relevant analysis by Wittgenstein addresses significantly different issues). See Wittgenstein, L.: Philosophical Investigations. Oxford, 1958, s. 201. See further Dummett: op. cit. 464.

${ }^{7}$ Cf. Hacking, I.: The Parody of Conversation. In: LePore (ed.): Truth and Interpretation... op. cit. 451 . See further Dummett: op. cit. 464. 
about intentionalism as the subject of the present paper, I will focus on statutory interpretation. I use the terms "legal interpretation" and "statutory inter Allan pretation" interchangeably below.

There is a crucial methodological point that I will rely on throughout this essay but that I will not try to justify in detail: a normative theory of legal interpretation cannot be some general theory of interpretation applied to law. The character of statutory interpretation is very much determined by its function: it serves a practical function in being part of a practice that seeks to provide practical guidance. This function has a lot to do with the way we think about the role of the legislature and the judiciary in the life of our society, that is, with issues concerning the proper allocation of institutionalized public authority in a political society. It cannot be an accident that most of the theoretical battles over legal interpretation are fought in the realm of constitutional theory. And, of course, constitutional theory heavily relies on political philosophy. ${ }^{8}$ Some of the relevant theoretical problems of legal interpretation must belong to practical philosophy, more specifically to political philosophy.

I do not argue, however, that the whole theoretical problem of legal interpretation belongs to political philosophy. Tom Campbell argues for something like this, and I would like to distinguish my position from his claims. Campbell does not deny that theories concentrating upon the general features of interpretation have a bearing on our understanding of legal interpretation. ${ }^{9}$ But he denies the possibility that we can lay the foundations of a normative theory of legal interpretation by way of a politically neutral conceptual analysis. The views we have about legal interpretation are ultimately dependent upon the way we perceive issue like that of the separation of powers, the role of the judges, etc.

Up to this point, I agree with Campbell's suggestions. However, he goes on to reconsider the very concept of legal interpretation. He treats theories of legal interpretation as being inevitably part of a broad political theory about the proper allocation of power in society. And as the whole theoretical issue is deeply embedded in political philosophy, it seems to him that "selecting a theory of legal interpretation (...) is not dependent on any general theory of

8 See Perry, M. J.: Why Constitutional Theory Matters to Constitutional Practice (And Vice Versa). In: Leyh, G. (ed.): Legal Hermeneutics: History, Theory, and Practice. Berkeley and Los Angeles, 1992. 250.

9 See Campbell, T.: Grounding Theories of Legal Interpretation. In: Goldsworthy, J.Campbell, T. (eds.): Legal Interpretation in Democratic States. Aldershot, 2002. 30. 
interpretation or controversial theory of meaning." ${ }^{10}$ This is where Campbell goes too far. What we can legitimately claim is that theories of general interpretation are indeterminate in respect of some crucial issues of legal interpretation, and they need to be supplemented with other (e.g. political philosophical) considerations. But even if the emphasis shifts towards political philosophy, we still need conceptions of legal interpretation that are consistent with some viable view on the general features of interpretation. In this sense, selecting a theory of legal interpretation is indeed dependent on general theories of interpretation. The practical philosophical considerations that help to account for the distinctive features of legal interpretation should not be taken as isolating the theoretical analysis from the broader philosophical problem of interpretation. ${ }^{11}$ General theories of interpretation are not unimportant for us, but what we can learn from them just cannot be enough to lay the foundations for a tenable normative theory of legal interpretation.

My analysis will face political philosophical problems that are identified as intrinsically relevant to normative theory of legal interpretation. However, the pertinent political philosophical issues will be left open for they cannot be answered adequately on the basis of the considerations mobilized by this essay. That is why I said in the first paragraph that the argument presented here would be incomplete.

Without accepting the abovementioned methodological point about the role of political philosophical considerations, I would not have written this particular essay. In respect of the general theories of interpretation, I happen to be a sort of intentionalist. I believe that any full understanding of a text must pay attention to the intentions that gave rise to the speaker's meanings in the interpreted text. If I could take it as implying the truth of intentionalism about legal interpretation, the refutation of non-intentionalism would not require a legal theoretical analysis. But the challenge of non-intentionalism is more stubborn. For one, non-intentionalists can accept that any full interpretation needs to pay attention to authorial intentions, and yet insist that legal interpretation aims at no more than a partial understanding of the legal text. It is possible that nonintentionalist interpretive strategies are capable of revealing the "legally relevant"

${ }^{10}$ Ibid. 33.

${ }^{11}$ For similar reasons, I reject attempts to reduce the whole activity of interpretation to some moral or political function. This view is well exemplified by Stanley Fish who regards interpretation as the effort of a morality (or agenda) "to extend itself into the world by inscribing its message on every available space". Fish, S.: There is No Such Thing as Free Speech and it's a Good Thing, Too. New York, Oxford, 1994. 142. I do not think that such approaches can be coherent. 
meanings of legal texts, while intentionalist strategies reveal something elsesomething legally irrelevant.

It indicates that we should pay attention to the features that make legal interpretation specific. As far as I can see, those features are associated with the close connection between legal interpretation and the process of making legal decisions. The following two of them are certainly crucial for us. The first is that legal interpretation has a strictly practical orientation. Legal interpretation seeks to reveal the practical guidance that the legal text provides, and remains indifferent to anything that goes beyond this task. The second feature is that legal interpretation raises issues concerning the agent of interpretation in a peculiar way.

The first distinctive feature makes it a prerequisite to any plausible theory of legal interpretation to have a good understanding of the kind of practical guidance that the law seeks to provide, and general theories of interpretation are unlikely to be able to facilitate this understanding. A general theory of interpretation can make us understand that legal interpretation is guided by practical orientations, ${ }^{12}$ but it cannot be specific enough in respect of the relevant practical orientations. ${ }^{13}$ Practical orientations have many versions, and it is simply beyond the reach of a general theory of interpretation to provide the necessary specification for the practical orientation inherent in legal interpretation. If we want to identify the kind of practical guidance characteristic of law, we face issues concerning the authority of law. Conceptual points about the authoritativeness of law will play a crucial role in the following analysis.

The second distinctive feature I mentioned manifests itself in the fact that legal interpretations carried out by the decision-makers have an overriding significance. Every lawyer knows that there are many ways of understanding the practical requirements involved in a particular legal directive, and many techniques of interpretation can be mobilized to support those "understandings". But the understanding that really matters is that of the judiciary. Once it is revealed, the debate over the correct interpretation of the directive becomes largely academic. ${ }^{14}$ This point is underlined by the fact that the overriding

${ }^{12}$ See Gadamer, H.-G.: Truth and Method. London, 1989. 324-341.

${ }^{13}$ This problem of specification is well brought out by Arthur Glass who rightly claims that Gadamer's concept of 'application' is far too ambiguous from a legal theoretical point of view. See Glass, A.: A Hermeneutical Standpoint. In: Goldsworthy-Campbell (eds.): Legal Interpretation in Democratic States. op. cit. 136. However, he seems to treat it as a shortcoming of Gadamer's analysis. In my view, it is not: it is an acceptable implication of the abstractness of Gadamer's analysis.

${ }^{14}$ Of course, there is an element of rhetorical exaggeration in this claim. The interpretations of legal texts by the police, prosecutors, administrative agencies, etc. all matter 
significance of the decision-makers' interpretations is not dependent on their expertise (on their epistemic authority). Judicial interpretations are often condemned as mistaken (even silly) and often for good reasons. Nevertheless, they can and do retain their priority to rival interpretations. They can be defeated not by providing a better interpretation of the misinterpreted legal directives but by setting in motion certain institutional procedures (like legislation or overruling).

It indicates that, for a normative theory of legal interpretation, considerations concerning the institutional characteristics of law can turn out to be more decisive than anything that we can learn from any general theory of interpretation. It seems to me that the most important current debates over legal interpretation (including the debate between the intentionalists and the nonintentionalists) cannot really be addressed by any approach that general theories of interpretation can offer. ${ }^{15}$ Non-intentionalists can still win the day if they are capable of building their claims on a superior understanding of the institutional features of legal interpretation.

\section{Legal authority and intentionalism}

We have seen that the character of legal interpretation is partly determined by the institutional features of law. However, the law has many institutional features, and most of them are largely irrelevant to our present concern. We need to point to the particular features that may prove decisive in respect of the debate over intentionalism.

Contemporary legal theorists have many suggestions concerning this issue. Some of them concentrate on substantive practical philosophical issues (like issues of legitimacy). Jeffrey Goldsworthy's suggestion points to a commitment to the value of legislative supremacy-a commitment deeply embedded in our ideas about constitutionalism. For Goldsworthy, legislative supremacy becomes an empty phrase if intentionalism fails. If the intentions of the legislators do not matter, we end up with some sort of judicial supremacy: the judges' own value judgements will guide and limit the changes of the meanings of statutes. ${ }^{16}$

(even when they disagree with the judges' understanding). But not in a way that would undermine the point I am trying to make.

${ }^{15}$ See Glass: op. cit. 146-147.

${ }^{16}$ See Goldsworthy, J.: Legislative Intentions, Legislative Supremacy, and Legal Positivism. In: Goldsworthy-Campbell (eds.): Legal Interpretation in Democratic States. op. cit. 55. Of course, substantive arguments can support non-intentionalism as well. See, 
I find this argument particularly attractive. But the argument relies on an intimate connection between issues of interpretive strategy and the authority relations inherent in the institutional structure of law. That connection cannot be established without revealing important conceptual points about the authority of law. Substantive arguments like this must be built upon the relevant conceptual arguments. ${ }^{17}$ This is why my analysis will concentrate on conceptual arguments concerning intentionalism and non-intentionalism.

Many contemporary legal theorists believe that the decisive conceptual feature of law that is ultimately relevant to the debate over intentionalism concerns the authority relations on which the whole structure of law was built. Some of them also believe that understanding the characteristics of legal authority vindicates intentionalism. In the following analysis, I will take this view as the standard conceptual justification of intentionalism. The rest of the views will be seen as challenges to this argument.

We can easily point out the connection between the problem of legal authority and legal interpretation. I have mentioned above that legal interpretation aims at understanding the practical guidance that the law provides to us by way of the legal text. As practical guidance can be provided in many ways, it is part of the interpretive task to understand the nature of the practical guidance provided by the law. Successful legal interpretations presuppose a good understanding of the difference the law makes to our lives.

Sometimes the practical guidance consists in revealing reasons that are worth considering. (This is a version of giving advice.) But the law is not a system that seeks to give us mere advice. Sometimes the practical guidance helps us understand the connection between some pre-existing duty and a certain course of action. But it is not characteristic of the law to refer back to preexisting duties. On other occasions the practical guidance itself creates a duty to behave in a certain way. In this case, the practical guidance is of an authoritative nature. Many claim that this is exactly the kind of practical guidance that that law typically provides. In the typical case, legal interpretation must lead to understanding the directives of law as authoritatively binding on us.

But how is this related to the issue of intentionalism? The key consideration is that legal directives are not genuinely authoritative. It is the nature of

e.g., Ball, T.: Constitutional Interpretation and Conceptual Change. In: Leyh (ed.): Legal Hermeneutics... op. cit. 133-134.

${ }^{17}$ On the level of conceptual analysis, it may turn out that Goldsworthy's claim partly misconceives the problem of legislative supremacy. For a suggestion to this effect, see Allan, T. R. S.: Constitutional Dialogue and the Justification of Judicial Review. In: 23 (2003) Oxford Journal of Legal Studies, 563-584. 575. 
authority relations that they are constituted as human relations. ${ }^{18}$ Only persons or groups of persons can have genuine authority. Legal directives are always issued by persons or groups of persons, and must be taken as manifestations of their authority claims. The legal directives that we reveal from legal texts have some kind of derivative authority: they are always some person's (or persons') judgement on other people's conduct. ${ }^{19}$ The function of legal texts is to help us figure out what practical guidance the genuine authorities have given to us.

This formulation of the features of legal authority undeniably lends some support to intentionalism. It seems that such considerations (and some related ones) underlie Joseph Raz's claim that the justification for treating law as valid derives from the authority of its makers, and laws are to be understood in light of the intentions of their makers. It is built into the notion of practical authority that law claims. ${ }^{20}$ Larry Alexander and Andrei Marmor, who use Raz's theory of authority as a starting point, are both committed to pretty much the same view. ${ }^{21}$

\section{Challenges to intentionalism I.: The availability of legislative intentions}

We now have an idea of the standard conceptual justification of intentionalism. We can begin to assess the challenges to it. As the pertinent version of intentionalism relies heavily on explaining the normativity of law in terms of certain authority relations, one obvious way of challenging this view is to call into question the account of legal authority underlying it. There are authors who deny that the law claims authority, ${ }^{22}$ and there are others who deny that law can have practical authority. ${ }^{23}$ Their views are certainly relevant for us, particularly because some of them have been explicitly used to put forward non-intentionalist claims about legal interpretation. ${ }^{24}$ However, I set aside those

${ }^{18}$ Cf. Raz, J.: Ethics in the Public Domain. Oxford, 1994. 216-217.

${ }^{19}$ See ibid.

${ }^{20}$ See Raz, J.: Why Interpret? In: Ratio Juris, 9 (1996) 359. See further Raz, J.: Intention and Interpretation. In: George, R. P. (ed.): The Autonomy of Law: Essays on Legal Positivism. Oxford, 1996. 280.

${ }^{21}$ See Alexander, L.: All or Nothing at All?: The Intentions of Authorities and the Authority of Intentions. In: Marmor (ed.): Law and Interpretation... op. cit. 358-363. Marmor: Interpretation and Legal Theory. op. cit. 176.

${ }^{22}$ See, e.g., Soper, Ph.: The Ethics of Deference. Cambridge, 2002. xiv. and 54.

${ }^{23}$ See, e.g., Hurd, H. M.: Sovereignty in Silence. In: 99 (1990) The Yale Law Journal, 945-1028. 1007-1022.

${ }^{24}$ See e.g. Hurd, H. M.: Interpreting Authorities. In: Marmor (ed.): Law and Interpretation... op. cit. 
suggestions in the present essay. A proper assessment of them would require us to provide an extensive discussion of the theoretical problem of authority and the conceptual characteristics of law, and that would go well beyond the ambitions of the present inquiry. I am convinced, however, that there are important conceptual characteristics of law that cannot be accounted for if we deny that law claims practical authority. I have expressed and defended that conviction elsewhere. ${ }^{25}$ I restrict myself to the claim that an analysis of the normativity of law that remains within the boundaries of the Razian account of practical authority is still the best available theoretical option for us. I accept that most of the claims I make in this essay stand and fall with this controversial commitment.

We had better turn now to other challenges to the standard conceptual justification of intentionalism. Many non-intentionalists think that the best way to undermine the intentionalist position is calling into question our ability to retrieve any legislative intention that could be used as a basis for interpretive claims. In the relevant sense, there is no legislative intention that could help the intentionalist. In the past twenty years, two important and influential authors, Ronald Dworkin and Jeremy Waldron, have put forward non-intentionalist claims along these lines. They certainly deserve some attention here.

Let me start with Waldron's arguments. His central claim revolves around the obvious fact that modern statutes are produced by the deliberations of large multi-member assemblies. ${ }^{26}$ Waldron readily admits that intentionality plays a crucial role in the legislative process. ${ }^{27}$ The specific target of his critique is the concept of "the intention of the legislature": there is no state or condition corresponding to this concept. It makes sense to talk about the intentions of the individual legislators but attributing particular intentions to the legislature or the statute is a different matter. Individual intentions usually point to various directions, and what we know about the intentions of individual legislators is not enough to settle any interpretive dispute (even though such intentions can be loosely associated with the human authorship of the statute). Hence, intentionalism must be wrong.

The trouble with this argument is that what we have here is not really a refutation of the conceptual possibility of finding genuine legislative intentions

\footnotetext{
${ }^{25}$ See Bódig, M.: Jogelmélet és gyakorlati filozófia: Jogelméleti módszertani vizsgálódások [Jurisprudence and Practical Philosophy: Jurisprudential Methodological Investigations]. Miskolc, 2004. 525-527.

${ }^{26}$ See Waldron, J.: Legislators' Intentions and Unintentional Legislation. In: Waldron: Law and Disagreement. Oxford, 1999. 121.

${ }^{27}$ See ibid. 142.
} 
behind a product of legislation but some difficulties that make it often difficult or even hopeless. It seems to me that that makes Waldron's argument ineffective against several forms of intentionalism. The argument is ineffective against relying on "legislators' intentions" in a minimalist sense: the legislators participate in a process that has legislative effect, and understand the process as having that function. On this ground, we can ascribe to the legislative body the intention that the enacted clauses should take effect as valid legal rules. ${ }^{28}$ It is more important to us that there is room here for another, slightly stronger sense of "legislators' intentions". Quite wisely, Waldron does not deny the possibility of group intentions. ${ }^{29}$ A combination of intentions can sometimes amount to a collective intention, ${ }^{30}$ and we have no reason to deny that it can happen to legislative assemblies as well. But admitting this amounts to saying that the intentionalist approach can work at least in some cases. ${ }^{31}$ Hence, Waldron's argument is strong enough to force the intentionalist to admit that intentionalist interpretive strategies can break down. Furthermore, it may be strong enough to show that it can happen very often. However, these are claims that a sensible intentionalist would not deny anyway. It is enough for her to claim that legislative intentions matter in legal interpretation-when they are available.

Let me turn now to Ronald Dworkin. As is well known, his Law's Empire has a series of arguments that are directed against a form of intentionalism. ${ }^{32}$ These arguments are well known, and I will not rehearse them here. But let us look at the exact target of his arguments. He calls his target the "speaker's meaning view" of statutory interpretation: "it assumes that legislation is an occasion or instance of communication and that judges look to legislative history when a statute is not clear on its face to discover what state of mind the legislators tried to communicate through their votes." ${ }^{33}$ So the target is an extreme version of intentionalism that sees the task of the interpretive enterprise in retrieving certain mental states of the legislators. I have no wish to deny that Dworkin's

${ }^{28}$ See MacCormick, N.: Legal Reasoning and Legal Theory. Oxford, 1978. 209. In a sense, even Waldron grants this. See Waldron: op. cit. 127.

${ }^{29} \mathrm{He}$ seems to admit the theoretical possibility of an "Aristotelian synthesis" of the views and actions that contributed to the legislative process. See Waldron: op. cit. 136138. Andrei Marmor certainly took advantage of this when he tried to reply to Waldron's non-intentionalist arguments. See his Authorities and Persons. In: Legal Theory, 1 (1995) 337-359., 341-342.

${ }^{30}$ See Bratman, M.: Shared Intention. Ethics, 104 (1993) 97-113.

${ }^{31}$ Jeffrey Goldsworthy is quite right in claiming that common sense sometimes can reveal legislative intentions. See Goldsworthy: op. cit. 49.

${ }^{32}$ See Dworkin, R.: Law's Empire. London, 1986. 317-327.

${ }^{33}$ Ibid. 315. 
arguments are devastating for those who are committed to this "psychologised" version of intentionalism. But we can talk about legislative intentions in more than one sense, ${ }^{34}$ and there can be versions of intentionalism that are not guilty of this rough "psychologism". As a matter of fact, one can see in contemporary versions of intentionalism a strong "depsychologising" tendency. Raz's "interpretation without retrieval" ${ }^{35}$ the concept of "inchoate intention" developed by Alexander and Sherwin, ${ }^{36}$ or Allan's "constructive intention" ${ }^{37}$ are all instructive examples in this respect. ${ }^{38}$ In contemporary legal theory there has been much argument about the meaningfulness of attributing intentions to legislative bodies. It seems to me that the actual upshot of those arguments is that we see the inadequacy of a certain "psychologising" approach to legal interpretation that was doomed anyway.

\section{Challenges to intentionalism II.: The problem with old laws}

In my view, the most serious challenge to the standard conceptual justification of intentionalism is what we may call the problem with old laws. I have indicated that the legislators' intentions matter because they have authority over us. But what if it makes no sense, at least in a number of cases, to speak of the authority of those who enacted the interpreted statute? Some claim that this is exactly the case with laws enacted long ago. Michael Moore, for example, makes a case for non-intentionalism partly by claiming that much

\footnotetext{
${ }^{34}$ Cf. Bix, B.: Questions in Legal Interpretation. In: Marmor (ed.): Law and Interpretation... op. cit. 142-146.

${ }^{35}$ See Raz, J.: Interpretation Without Retrieval. In: Marmor (ed.): Law and Interpretation... op. cit.

${ }^{36}$ See Alexander, L.-Sherwin, E.: The Rule of Rules: Morality, Rules, and the Dilemmas of Law. Durham, London, 2001. 7-14.

${ }^{37}$ See Allan: Constitutional Dialogue... op. cit. 581. See further Allan, T. R. S.: Legislative Supremacy and Legislative Intent: A Reply to Professor Craig. In: Oxford Journal of Legal Studies, 24 (2004) 4. 563-583. 568. It is worth noting that Allan's ideas concerning constructive intention are hotly debated by Paul Craig, and Allan's ideas have been developed partly in the debate with Craig. See Craig, P.: The Common Law, Shared Power and Judicial Review. Oxford Journal of Legal Studies, 24 (2004) 2. 237-257., 241242. Craig. P.: Legislative Intent and Legislative Supremacy: A Reply to Professor Allan. 24 (2004) 4. Oxford Journal of Legal Studies, 24 (2004) 2. 585-596., 585-587.

${ }^{38}$ Ironically, even Dworkin can be seen as advocating some sort of a "depsychologised" intentionalism. The judge who represents Dworkin's ideal of proper statutory interpretation "will treat Congress as an author earlier than himself in the chain of law." Dworkin: op. cit. 313.
} 
of the legal material to be interpreted was created by people who have no authority above us. Their "authorship" cannot account for the claims the legal documents make on our actions. ${ }^{39}$

As far as I can see, contemporary intentionalists do not have a good answer to the problem of old laws. Andrei Marmor, for example, sees it as a problem of legal validity: we need to explain the continuing validity of the norms of the legal system. He claims that this continuing validity is determined by certain rules or conventions. ${ }^{40}$ These rules or conventions may be regarded as part of the "rule of recognition" of the pertinent legal system. The problem is that this suggestion heavily relies on a form of legal positivism (a conventionalist view of the normativity of law) that is highly controversial. In fact, I regard that version of legal positivism as profoundly mistaken. ${ }^{41}$ So I shall keep away from it.

In my view, the best effort to tackle the problem is made by Joseph Raz. His solution is based on the idea that continuity is a prominent value in legal systems. We attribute legal normativity to old laws because we respect the ethical reasons that call for continuity in the operations of the legal system. ${ }^{42}$ This may be the best available effort but it still seems problematic to me. It implies that there is a crucial difference between new laws and old laws in respect of the grounds of their normativity. In the case of new laws, these grounds are associated with the authority of their makers, while in the case of old laws they are associated with certain specific moral values. The problem is that this view presupposes that some laws are normative for different reasons than others in our legal systems, and I see no reason to accept this presupposition. ${ }^{43}$ We should have a better way of handling the problem with old laws.

\section{Authority and sovereignty}

The problem with old laws may well be taken as indicating that we should dig deeper into the implications of the view that the features of legal authority have a crucial impact on the issue of proper interpretive strategy. The source of the problem is obvious. The account of legal authority that we relied on

${ }^{39}$ See Moore: op. cit. 14.

${ }^{40}$ See Marmor: Authorities and Persons. op. cit. 355.

${ }^{41}$ See Bódig: op. cit. 63-102.

${ }^{42}$ See Raz: Why Interpret? op. cit. 359.

${ }^{43}$ I do not claim that all laws should be taken as authoritative for exactly the same reasons in a legal system. But Raz's view allows for a divergence of the reasons underlying the normativitity of different laws that I do not find tolerable. 
assumed that legal authority is a relation between human beings: it has a personal element. It serves the intentionalist position well in certain respects (it explains quite neatly why the legislators' intentions matter), but it leads to problems where the personal "bond" between the authority and the subjects is broken though the directives issued by the authority still claim to be authoritatively binding.

We need a better understanding of the authority relations involved in legal decision-making. It may be that, at the end of the day, we will be forced to accept Waldron's suggestion that we should not treat the authority of the legal text as dependent on the authority of its authors. We have got to give up the "personification" of legal authority: we have got to attribute impersonal authority to legislative decisions.

This claim happens to be another limb of Waldron's non-intentionalist argument that we have taken into consideration above. According to Waldron, the authority of statutes has not much to do with the personal qualities of the legislators for the authority claim inherent in those statutes "consists in their ability to integrate a diversity of purposes, interests, and aims among their members into the text of a single legislative product". ${ }^{44}$ If the integration of the diverse purposes could be carried out by an impersonal mechanism, it would have an equally legitimate claim to authority. ${ }^{45}$

I have no wish to consider here Waldron's suggestions concerning the reasons that make subjection to the authority of an impersonal mechanism reasonable. Even if they were appealing, Waldron would still miss the point. The standard conceptual justification of intentionalism is not based on justificatory claims concerning certain possible versions of legal authority: it is based on an account of the conceptual features of legal authority. So the real question is whether Waldron's suggestions ${ }^{46}$ are capable of giving a better account of those features. And it seems that they are not. Waldron's impersonal conception of legislative authority cannot account for at least one important feature of the normative force of legal directives: their (relative) contentindependence. ${ }^{47}$ One can hardly attribute content-independent normative force to impersonal mechanisms. ${ }^{48}$

${ }^{44}$ Waldron: op. cit. 121.

${ }^{45}$ See ibid. 126-127.

${ }^{46}$ See ibid. 131.

${ }^{47}$ See Marmor: Authorities and Persons. op. cit. 345-346.

${ }^{48}$ It is something that seems to be implied in the very definition of content-independence. When Joseph Raz characterizes the content-independence of authoritative directives one of 
It seems to me that the idea that legal authority is based on relations between persons is basically sound. But we have to make clearer the personal element of legal authority. We have got to see that legal authority is personal in a relatively weak sense. To see an authority relation that is personal in a strong sense, we may point to parental authority. It is so strongly personal that, in a sense, it excludes succession. It sometimes happens that a man takes the position of the original father in the family. Can we say that the stepfather's role will be a continuation of the parental authority of the original father? I do not think so. The stepfather will not become a proper authority without successfully establishing a unique personal relationship with the children. ${ }^{49}$ Without that, he will never have proper parental authority (no matter what the law says). And, if he does establish the necessary personal relationship successfully, his authority will have not much to do with the parental authority of the original father. It will be a new authority relation and not the continuation of a previous one.

Legal authority is not personal in this sense. Old legal officials are often replaced with new ones but it would be silly to claim that the newly appointed officials need to establish some special personal relationship with anyone in order to become proper legal authorities. They are proper authorities from the very moment of their appointment, and their practice is the continuation of the practice of their predecessors. If there are unfinished jobs (undecided cases) left by their predecessors, it will be their duty to finish them, and it will not be a new procedure in any relevant sense.

What should all this indicate to us? I think the difference between legal and parental authority has a lot to do with the fact that the legal official, unlike the father, does not stand for himself in the authority relation. It is not her person that matters but the role she plays. This is why she can be replaced without destroying the authority relation. One way of putting this insight is to say that the legal official is a representative (while the father does not represent anyone). For this reason, let me call the legal officials' authority "representational authority". 50

the features he mentions is that "his saying so would be reason for any number of actions". See his The Morality of Freedom. Oxford, 1986. 35.

${ }^{49}$ Of course, I have no wish to deny that someone who "takes up" the role of father may have roughly or exactly the same rights and duties as someone who had that role biologically.

${ }^{50}$ This consideration is relevant to one of Waldron's further claims. He argues that intentionalism is in conflict with the rule law, and, for this reason, it raises legitimacy problems. If we suppose that the legislators have personal authority over the law they enact "it is impossible that a law could have authority vis-à-vis a legislator." Waldron: op. cit. 
Some elements of this claim can be found in several theoretical accounts, ${ }^{51}$ and it is should sound familiar for those aware of the ordinary facts of everyday legal practice. Judges do not announce their decisions in their own name: they announce them in the name of the Republic or the Crown or something like that. Statutes are not kept in the archives under the name of the particular legislators. ${ }^{52}$ But how could it provide the basis for tackling the problem with old laws? Well, it allows us to say that, in the case of legislative authority, it is not a particular group of legislators to which we should attribute authority but an institutionalized assembly that is "filled" with different members time to time without any real change in the character of the underlying authority relation. Even if all the former members are replaced with new ones, the proceedings of the assembly will be the continuation of the same authority relation. Old laws have the same authority as the new ones if they are associated with the same authority relation. They are embedded in a continuous authoritative practice. ${ }^{53}$

It seems obvious to me that this revised version of the standard conceptual justification is still good enough to give support to the intentionalist cause. Institutions like legislative assemblies do not exercise their authority without having members who act in their name. Although the legislators are only representatives, as long as they hold their positions in the legislature they are the ones who are entrusted to provide practical guidance in the form of statutes: their intentions matter. And, in this respect, there is no difference between the legislators of the present and the past. ${ }^{54}$

139. We can fend off this objection, however, by insisting that the legislators have personal authority over the law only within the limits of their institutional role. In every other respect, they are no less bound by it than any other subject. See Marmor: Authorities and Persons. op. cit. 355.

${ }^{51}$ Cf. Raz, J.: On the Authority and Interpretation of Constitutions: Some Preliminaries. In: Alexander, L. (ed.): Constitutionalism: Philosophical Foundations. Cambridge, 1998. 184185. See further Marmor: Authorities and Persons. op. cit. 355.

${ }^{52}$ Cf. MacCormick, N.: Norms, Institutions, and Institutional Facts. Law and Philosophy. 17 (1998) 301-345. 332.

${ }^{53}$ Of course, there may be complications with this approach. As the right to legislate is sometimes transferred from one assembly to another, we will have to cope with the problems of institutional change.

${ }^{54}$ This point could be amplified by a consideration that I largely ignore here. The fact that different legal officials operate within the framework of identical or closely related authority relations manifests itself in the fact that the legislators' decisions become embedded in the practice of many other officials who will inevitably shape them. Later legislators amend the old statutes, and the judicial practice has an impact on the ways they are understood. 


\section{Legal Authority and Sovereignty}

Though this may sound promising, the analysis is in need of a series of further clarifications if it is to be regarded as really successful in solving our problems with old laws. We have got to provide an answer to the question: "who is represented by the legislators?" There are two kinds of answers that certainly will not do here. It would be misguided to claim that legislators are representatives of the law because our problem raises questions about the way the law itself becomes authoritative. The very existence of law presupposes certain authority relations that we have to account for here. It would be equally misguided to claim that legislators are the representatives of the legislative assembly to which they belong. Legislative bodies do not exist until they are set up by certain people.

It is quite clear what kind of answer we need. If we raise questions concerning the grounds of the officials' authority we want to know something about sovereignty. The issue of sovereignty is a tricky issue partly because sovereignty can have several sources and can take several forms. But this is not the real problem: we can restrict our attention (without fatally undermining the validity claims of our analysis) to the case of constitutional democracies where we have a standard answer to the question of the source of authority. In respect of constitutional democracies, the first step in the analysis is easy. The legislators openly announce themselves as representatives: representatives of the people. It seems that we need to look for some conception of popular sovereignty, and the legislators should be treated as representatives of the political community as a whole. However, a series of conceptual problems are likely to arise at this point. One could say that political communities are not agents: they never make decisions, and never set up institutions. And although the political community's inability to act explains why it needs representatives, it is likely to make highly controversial any suggestion concerning the process that endows legal institutions and officials with their authority.

Of course, there can be ways of handling this problem. For example, we can take recourse to political morality, and argue that some shared political morality turns a multitude of people into a political community. ${ }^{55}$ Then, official action (and, most of all, the legislative practice) can be treated as authoritative as long as it remains within the boundaries of that shared political morality. Justificatory question concerning the practice of the officials can be tentatively answered with the help of a legitimising process in which the ordinary members of the political community are invited to participate. Unfortunately, this line of

\footnotetext{
${ }^{55}$ See Bódig: op. cit. 540-541.
} 
argument is likely to lead to a series of controversial and rather counterintuitive claims-and not only because one can reasonably doubt whether we can in fact find a shared political morality in an existing political community. There is something odd in treating the law as being based on a pre-existing political morality. Typically, it is the law (especially the Constitution) that helps people acknowledge the issues of political morality, and it functions as the best reliable source of information about the political morality of their community.

Although I have struggled with them ${ }^{56}$ I have no wish to pretend that I know how to handle those extremely complicated issues. However, I am sure that we have to confront them if we work on normative theories of legal interpretation. It does not mean that anyone who is about to rely on intentionalist interpretive strategies must tackle the problems of sovereignty. But the theoretical efforts cannot escape them. In order to have a proper understanding of the distinctive features of legal interpretation, we need to refer to the grounds of law's normativity, and it leads to some of the complicated problems of normative political theory.

It is important to emphasise that the core idea that I set forth here is not at all alien to contemporary analyses of the problem of legal interpretation. ${ }^{57}$ It is hard to deny that legal interpretation has a lot to do with the proper allocation of institutionalized public authority in a society. When the constitutional interpretation is at issue, legal theorists tend to realise this. Both Joseph Raz's and Michael Moore's accounts of constitutional interpretation heavily rely on claims concerning the grounds of the normativity of the Constitution. ${ }^{58}$ In this that respect, most legal theorists realise that the theoretical problems of legal interpretation raise political philosophical issues. We need to take it seriously when we conduct our debates over intentionalism.

${ }^{56}$ See ibid. $525-535$.

${ }^{57}$ See Allan: Constitutional Dialogue... op. cit. 582-583.

${ }^{58}$ See Raz: On the Authority and Interpretation of Constitutions. op. cit. 173. See Moore: op. cit. 14. 